\title{
Effects of Deficit Irrigation on Hull Rot Disease of Almond Trees Caused by Monilinia fructicola and Rhizopus stolonifer
}

\author{
B. L. Teviotdale, Department of Plant Pathology, D. A. Goldhamer, Department of Land Air and Water Resources, \\ University of California Davis, Kearney Agricultural Center, Parlier 93648; and M. Viveros, University of Califor- \\ nia Cooperative Extension, Bakersfield 93370
}

\begin{abstract}
Teviotdale, B. L., Goldhamer, D. A., and Viveros, M. 2001. Effects of deficit irrigation on hull rot disease of almond trees caused by Monilinia fructicola and Rhizopus stolonifer. Plant Dis. 85:399-403.

Almond trees were irrigated from March through November 1994 and 1995 with 70, 85, and $100 \%$ of potential evapotranspiration (ETc). Deficit irrigation was accomplished by delivering 70 or $85 \%$ of ETc at every irrigation (sustained) or $50 \%$ of ETc during 1 June to 31 July (70 regulated) or 1 to 15 July (85 regulated). The natural incidence of dead leaf clusters and dead spurs, twigs, and small branches, measured at harvest, lessened with decreasing amounts of water, and regulated deficits were more effective than sustained deficits in reducing disease. Fruit at early dehiscence on trees in each of the five irrigation treatments were inoculated with $0.1 \mathrm{ml}$ of suspensions of $10^{4}$ spores per $\mathrm{ml}$ of Monilinia fructicola or Rhizopus stolonifer. Monilinia fructicola caused more hull rot than $R$. stolonifer, and both pathogens responded similarly to the irrigation treatments. The rate of fruit maturation was monitored for approximately 4 weeks before harvest by scoring the percent abscission and dehiscence and measuring the hull moisture content of fruit on trees in each irrigation treatment. Dry kernel weight was determined at harvest. Maturation was slower and kernel weight greater in treatments receiving $85 \%$ of ETc than $70 \%$ or those under sustained compared with regulated irrigation regimes.
\end{abstract}

Hull rot disease of almond, Prunus dulcis (Mill.) D. A. Webb, begins with gray to brown lesions on the mesocarp (hull) of maturing almond fruit. Leaves near some infected fruit and part or all of the subtending spur or shoot are killed. In summer, clusters of dead leaves are easily visible scattered among the healthy green foliage, and in severe cases, small branches die. Death of these tissues is attributed to fumaric acid, or a derivative, produced in the hull by the pathogens and transported to the leaves and shoots (5). The black vascular elements in the dead spurs and wood can be traced back to a pedicel or an infected fruit. The kernel is not harmed, but destruction of fruiting wood reduces yield (1). Many infected fruit do not fall during mechanical harvest and must be removed by expensive hand harvest because fruit left in the tree serve as overwintering sites for the navel orangeworm Amyelois transitella (Walker), a serious insect pest of almond $(13,14)$. The disease is most common in the cultivars Nonpareil, Kapareil, and Sonora (7).

Corresponding author: B. L. Teviotdale

E-mail: betht@uckac.edu

Accepted for publication 4 December 2000

Publication no. D-2001-0212-02R

(C) 2001 The American Phytopathological Society
Hull rot is usually caused by Rhizopus stolonifer (Ehrenb.:Fr.) Vuill. or Monilinia fructicola (G. Wint.) Honey and rarely by M. laxa (Aderhold \& Ruhland) Honey, $R$. circinans Tiegh., and $R$. arrhizus A. Fischer (6). Rhizopus spp. produce dense, black sporulation between the hull and shell, and the buff colored sporulation of M. fructicola develops on exterior and interior hull surfaces. The pathogens cause similar symptoms, and the mechanism of pathogenesis is presumed to be the same for all. The fungi cannot penetrate the exterior hull tissues, thus infection occurs through the inner hull surface after the hull dehisces along the ventral suture. As the fruit ripens, the suture widens, and the hull detaches from the pedicel and loses moisture. Leaf death is more likely when fruit are infected during early than late dehiscence, and $M$. fructicola usually causes more leaf death than $R$. stolonifer (12).

Chemical controls are not available for hull rot, but the disease is an excellent candidate for management through cultural practices. Vigorous heavily cropped trees that are supplied with plentiful nitrogen and water sustain the greatest damage (7). Eliminating irrigation during the 2 weeks preceding harvest reduced hull rot by 400 to $500 \%$ in two consecutive years (11). However, denying trees water for such long periods in the hot dry summers in California may jeopardize the crop (3). Less drastic reductions in water also may effectively reduce hull rot. Our objective in this work was to determine the effects of deficit irrigation on the incidence of hull rot disease caused by $M$. fructicola and $R$. stolonifer.

\section{MATERIALS AND METHODS}

Irrigation. The experiments were conducted in 1994 and 1995 in a commercial almond orchard in Kern County, CA. Trees of cultivars Nonpareil and Carmel were planted in 1975, spaced $7.6 \mathrm{~m}$ apart within and between rows, in an alternating pattern of two rows of Nonpareil next to one row of Carmel. Each experimental plot was six rows wide by eight trees long with two Nonpareil rows in the center. Data were collected from the central 12 (two rows of six trees each) Nonpareil trees.

Microsprinklers (40 liters/h, circular pattern, $3.5 \mathrm{~m}$ diameter) located midway between the trees in the tree row were used to apply water periodically from March though November each year. Application rates were 70,85 , and $100 \%$ (control) of potential evapotranspiration (ETc), depending upon the irrigation treatment. The ETc was calculated from reference crop water use (ETo) and almond crop coefficients (2). The modified Penman equation (10) was used to calculate ETo based on weather data collected by a nearby $(15 \mathrm{~km})$ automated weather station which was part of the California Irrigation Management Information System (CIMIS). The irrigation frequency was determined by the ETc and varied from 3 to 7 days. Irrigation frequency was the same for all treatments during the season, and irrigation duration was always $24 \mathrm{~h}$. Deficit irrigations were applied by adjusting the microsprinkler nozzle sizes and operating pressures while maintaining irrigation duration and frequency.

There were two types of deficit irrigation: sustained and regulated. The sustained was accomplished by irrigating at $70 \%$ (70 sustained) or $85 \%$ (85 sustained) of ETc at every irrigation throughout the season. The regulated treatments were irrigated at $100 \%$ of ETc except during 1 to 15 July (85 regulated) or 1 June to 31 July (70 regulated), when irrigation was 50\% of ETc. The irrigation schedules and amounts of water delivered from March through harvest (mid-August) each year are shown in Table 1. There were six replications of each treatment arranged in a randomized complete block design. 
Inoculum preparation. One isolate each of $M$. fructicola and $R$. stolonifer obtained from almond fruit were grown on acidified potato dextrose agar (APDA, 2.5 $\mathrm{ml}$ of $25 \%$ lactic acid [ $\mathrm{vol} / \mathrm{vol}$ ] per liter of medium) for 7 to 10 days at 20 to $22^{\circ} \mathrm{C}$ under diurnal laboratory light conditions. Spores were washed from culture plates with sterile, deionized water, passed through three layers of cheesecloth to remove mycelial fragments and clumped spores, counted with a hemacytometer, and adjusted to $10^{4}$ spores per $\mathrm{ml}$ with sterile, deionized water. Spore suspensions were prepared immediately before use and stored in an ice chest while in the field. Germination was determined by counting 100 spores in each of two APDA culture plates seeded with $0.1 \mathrm{ml}$ suspension after incubation at 20 to $22^{\circ} \mathrm{C}$ for $6 \mathrm{~h}(R$. stolonifer) or $24 \mathrm{~h}$ (M. fructicola). Germination ranged from 92 to $98 \%$.

Inoculation. One data tree bearing a sufficient number of healthy, dehisced but firmly attached fruit that were located next to healthy leaves and could be reached from the ground was chosen in each plot. Each of 25 fruit, scattered throughout the lower tree canopy, was inoculated with approximately $0.1 \mathrm{ml}$ of inoculum of $M$. fructicola or $R$. stolonifer or kept as a noninoculated control on 21 July both years. Inoculum was introduced into the open suture of each fruit using a hand pump atomizer.

Fruit maturation. The rate of fruit ripening was evaluated by monitoring the progress of hull abscission, dehiscence, and moisture content. At early dehiscence in mid-July each year, when $5 \%$ or fewer fruit on most trees had begun to dehisce, we tagged 50 fruit that had closed or only slightly open sutures. These fruit were located on the southeast side of the southernmost data tree in the west row of each plot. The stages of abscission and hull dehiscence of these fruit were evaluated on 15, 22, and 29 July and 3 August 1994 and on 13, 21, and 28 July and 4 August 1995. Abscission was visually estimated as the percentage of the pedicel circumference that was physically separated from the hull and was rated as $1=$ none, $2=1$ to $10 \%, 3$ $=11$ to $25 \%, 4=26$ to $50 \%, 5=51$ to
$75 \%$, and $6=76$ to $100 \%$. Dehisced fruit were defined as those with suture openings that were 2 or more mm wide. On each evaluation date, 10 healthy fruit were collected arbitrarily from each of these trees. The hulls were removed, weighed in the field, and returned to the laboratory where they were air-dried in a forced air oven (Soiltest Model L-72 C, Evanston, Illinois) at $65^{\circ} \mathrm{C}$ for $72 \mathrm{~h}$. Dry weights were recorded, and percent hull moisture was calculated from these values.

Disease evaluation. Inoculated and control fruit were collected, and the condition (healthy or dead) of their nearby leaves was recorded on 8 August 1994 and 4 August 1995. Trees were shaken for harvest on 9 August 1994 and 16 August 1995. The incidence of natural infection was determined on 11 August 1994 and 18 August 1995 by counting the clusters of dead leaves and visually estimating the total length of dead spurs, shoots, and small branches (dead wood) found in each of the 12 data trees. On the same days, more than 100 fruit were gathered randomly from beneath the data trees in each plot to assess hull infection. Hulls from all fruit in the inoculation experiments and 100 hulls drawn from each sample gathered from the orchard floor were examined in the laboratory for lesions and pathogen identification. Pathogens were identified by direct observation of sporulation or occasionally by reisolation. During harvest, a random sample of $1.8 \mathrm{~kg}$ of fruit were collected from each replication, fumigated, air-dried, and the dry weight of 75 kernels per sample determined.

Plant water status. Predawn leaf water potential was measured, generally weekly, with a pressure chamber (Model 3005 Soil Moisture Equipment Co., Santa Barbara, CA). Limitations of time and resources precluded data collection from all replications, thus single leaves from each of four trees within one replication of each irrigation treatment were collected within the hour before dawn. The leaves were placed in the chamber within seconds of excision, and precautions were used to prevent leaf water loss during measurement (4). Weather data were taken by the same CIMIS station used to determine ETo.
Data analysis. The experimental design was a randomized complete block with six replications of the irrigation treatments. The treatment design for natural infection, fruit maturation, and kernel weight was a two-way factorial with irrigation as the main plot factor and year as the subplot factor. For the inoculation experiment, a three-way factorial was used with irrigation the main factor and pathogen and year the subplot factors. An arcsine transformation was performed on percent infected hulls and leaves and percent dehisced fruit before analysis of variance; actual data are presented. Means were separated by orthogonal contrasts. Predawn leaf water potential data were not analyzed because data were collected from only one replicate.

\section{RESULTS}

Natural infection. There were significantly more dead leaf clusters $(P=$ $0.0001)$, dead $\operatorname{wood}(P=0.0001)$, and infected hulls $(P=0.0001)$ in 1995 than in 1994. Significant interactions occurred between irrigation treatment and year for the number of dead leaf clusters $(P=$ $0.0145)$ and centimeters of dead wood $(P=$ $0.0404)$, primarily because the magnitude or direction of the difference between the control and 85 sustained varied between 1994 and 1995. Because of the interactions, data were analyzed separately for each year using a two-way analysis of variance.

In 1994, significant differences among irrigation treatments occurred in the amounts of dead leaf clusters and dead wood (Table 2). The amounts of dead leaf clusters and dead wood were similar in the control and the 85 sustained treatments but were significantly greater in trees irrigated with 85 than $70 \%$ of ETc and in trees irrigated with sustained than with regulated deficits. Percent hull infection was not affected by irrigation treatment. Results were similar in 1995 except that the control and deficit treatments did not differ significantly in the amount of dead wood present. $R$. stolonifer was the only hull rot pathogen present in infected fruit.

Inoculated fruit. The percentages of dead leaves $(P=0.0001)$ and infected hulls

Table 1. Schedules for deficit irrigation treatments and leaf water potential for almond trees, Kern County, CA

\begin{tabular}{|c|c|c|c|c|c|c|c|c|c|}
\hline \multirow{3}{*}{$\begin{array}{l}\text { Irrigation } \\
\text { treatment }\end{array}$} & \multicolumn{5}{|c|}{ Irrigation rate (percentage of control) } & \multirow{2}{*}{\multicolumn{2}{|c|}{$\begin{array}{c}\text { Total applied water }(\mathbf{m m}) \\
1 \text { Mar-15 Apr }\end{array}$}} & \multirow{2}{*}{\multicolumn{2}{|c|}{$\begin{array}{c}\text { Leaf water potential }^{z} \\
\text { MPa }\end{array}$}} \\
\hline & \multirow{2}{*}{$\begin{array}{c}\text { March } \\
1-31\end{array}$} & \multirow{2}{*}{$\begin{array}{l}\text { June } \\
1-30\end{array}$} & \multicolumn{2}{|c|}{ July } & \multirow{2}{*}{$\underset{1-15}{\text { August }}$} & & & & \\
\hline & & & $1-15$ & 16-31 & & 1994 & 1995 & 1994 & 1995 \\
\hline 100 (control) & & & & & $\ldots$ & 789 & 800 & -1.13 & -1.02 \\
\hline 85 sustained & 85 & 85 & 85 & 85 & 85 & 661 & 677 & -1.19 & \\
\hline 85 regulated & 100 & 100 & 50 & 100 & 100 & 692 & 710 & -1.13 & -2.19 \\
\hline 70 sustained & 70 & 70 & 70 & 70 & 70 & 612 & 601 & -1.39 & -1.61 \\
\hline 70 regulated & 100 & 50 & 50 & 50 & 100 & 571 & 557 & -1.39 & -1.53 \\
\hline
\end{tabular}

${ }_{\mathrm{y}}^{\mathrm{y}}$ Water was delivered by microsprinklers operated for $24 \mathrm{~h}$ at a frequency based on estimated evapotranspiration (ETc). The control was $100 \%$ of ETc, and reductions from the control were accomplished by delivering 70 or $85 \%$ of ETc at every irrigation (sustained) or $50 \%$ of ETc only during intervals (regulated).

${ }^{z}$ One leaf from each of four trees in one replication of each irrigation treatment measured within an hour of dawn on 21 and 28 July 1994 and 1995 , respectively. 
$(P=0.0033)$ were greater in 1995 than in 1994. There were significant interactions between pathogen treatment and year for the percentage of fruit associated with dead leaves $(P=0.0001)$ and percentage infected hulls $(P=0.0001)$. These interactions in the overall analysis occurred because the increase in leaf death and hull infection with $M$. laxa compared with $R$. stolonifer was greater in 1995 than in 1994. Thus, data were analyzed separately for each year using a two-way factorial with irrigation as the main plot factor and pathogen as the subplot factor. In 1994, the percent dead leaves differed significantly among irrigation treatments and between the control and the deficit treatments (Table 3). No significant differences were found between the control and the 85 sustained or the 70 and $85 \%$ of ETc treatments, but more leaf death occurred in sustained than in regulated treatments. Hull infection was not affected by irrigation treatments. Results were similar in 1995. In both years, percent dead leaves and infected hulls differed significantly among pathogen treatments, and more leaf death and hull infection occurred in inoculated than in control treatments and where fruit were inoculated with $M$. laxa than with $R$. stolonifer.

Fruit maturation and kernel weight. Fruit reached maturity by harvest in all irrigation treatments (Fig. 1). Data from the third evaluation date in both years were analyzed to determine possible effects of irrigation treatment on the rate of maturation. On those dates, there were significant differences in abscission rating, percent fruit dehiscence, and hull moisture content and kernel weight among irrigation treatments (Table 4). The control did not vary significantly from the deficit treatments in abscission rating but differed in percent dehisced fruit, hull moisture, and kernel weight. Abscission rating, percent hull dehiscence, and moisture content and kernel weight were similar in the control and $85 \%$ of ETc. Fruit abscised and dehisced more slowly and had heavier kernels in the $85 \%$ of and sustained irrigation treatments compared with the $70 \%$ of ETc and regulated irrigation treatments. Hull moisture content was significantly greater in the control than in the deficit treatments, but no differences were found between the control and the 85 sustained, 70 and $85 \%$ of ETc, or sustained and regulated deficit treatments.

Plant water status. Predawn leaf water potential was lower in the 70 than in the

Table 3. Effects of deficit irrigation on expression of hull rot symptoms in almond trees cultivar Nonpareil when fruit were inoculated with Monilinia fructicola and Rhizopus stolonifer, Kern County, CA

\begin{tabular}{|c|c|c|c|c|}
\hline \multirow[b]{2}{*}{ Treatment } & \multicolumn{2}{|c|}{ Dead leaves $(\%)^{\mathrm{v}}$} & \multicolumn{2}{|c|}{ Infected hulls $(\%)^{v}$} \\
\hline & 1994 & 1995 & 1994 & 1995 \\
\hline \multicolumn{5}{|l|}{ Irrigation $^{\mathrm{w}}$} \\
\hline 100 (control) & $45.3^{\mathrm{x}}$ & 49.8 & 67.7 & 57.8 \\
\hline 85 sustained & 41.8 & 53.1 & 63.8 & 61.5 \\
\hline 85 regulated & 28.3 & 32.1 & 62.8 & 51.3 \\
\hline 70 sustained & 35.1 & 40.1 & 65.9 & 55.3 \\
\hline 70 regulated & 23.7 & 31.7 & 57.4 & 49.1 \\
\hline \multicolumn{5}{|l|}{ Pathogen } \\
\hline Monilinia & 54.9 & 76.4 & 83.7 & 91.2 \\
\hline Rhizopus & 46.6 & 42.7 & 69.8 & 50.2 \\
\hline Noninoculated ${ }^{\mathrm{y}}$ & 2.9 & 10.2 & 36.7 & 23.9 \\
\hline \multicolumn{5}{|l|}{ Significance of $F, P=\mathrm{z}$} \\
\hline Irrigation & 0.0007 & 0.0177 & NS & 0.0963 \\
\hline \multicolumn{5}{|l|}{ Orthogonal contrasts } \\
\hline 100 versus deficits & 0.0020 & 0.0055 & NS & NS \\
\hline 100 versus 85 sustained & NS & NS & NS & NS \\
\hline 85 versus 70 & 0.0880 & NS & NS & NS \\
\hline Sustained versus regulated & 0.0010 & 0.0210 & NS & NS \\
\hline Pathogen & 0.0001 & 0.0001 & 0.0001 & 0.0001 \\
\hline \multicolumn{5}{|l|}{ Orthogonal contrasts } \\
\hline Inoculated versus control & 0.0001 & 0.0010 & 0.0010 & 0.0010 \\
\hline Monilinia versus Rhizopus & 0.0030 & 0.0010 & 0.0010 & 0.0010 \\
\hline Irrigation $\times$ pathogen & 0.0518 & NS & NS & NS \\
\hline
\end{tabular}

${ }^{v}$ Twenty-five healthy fruit per replication, each situated next to healthy leaves, were inoculated with a $0.1-\mathrm{ml}$ suspension each of $10^{4}$ conidia per $\mathrm{ml}$ of $M$. fructicola, R. stolonifer, or left noninoculated on 21 July 1994 and 1995. Fruit were collected to assess hull infection and the condition of nearby leaves recorded on 8 August 1994 and 4 August 1995. Trees were commercially harvested 9 August 1994 and 16 August 1995.

${ }^{\mathrm{w}}$ Irrigation deficits of 70 and $85 \%$ of potential evapotranspiration (ETc) were imposed at every irrigation (70 and 85 sustained) or by one preharvest reduction to $50 \%$ of ETc from 1 June to 31 July (70 regulated) or 1 to 15 July ( 85 regulated).

${ }^{x}$ Means are for main effects.

y Only $R$. stolonifer found in infected control fruit.

${ }^{\mathrm{z}}$ Irrigation treatments were replicated six times and arranged in a randomized complete block design. Overall significances of $F$ are for main effects and their interactions. Means were separated by orthogonal contrasts. NS = not significant, $P>0.1000$.

Table 2. Effects of deficit irrigation on natural incidence of hull rot disease caused by Rhizopus stolonifer in almond trees cultivar Nonpareil, Kern County, CA

\begin{tabular}{|c|c|c|c|c|c|c|}
\hline \multirow[b]{2}{*}{ Irrigation treatment ${ }^{\mathrm{x}}$} & \multicolumn{2}{|c|}{$\begin{array}{l}\text { Dead leaf clusters }{ }^{y} \\
\text { (no. per tree) }\end{array}$} & \multicolumn{2}{|c|}{$\begin{array}{l}\text { Dead wood } \\
\text { (cm per tree) }\end{array}$} & \multicolumn{2}{|c|}{$\begin{array}{c}\text { Infected hulls }^{y} \\
(\%)\end{array}$} \\
\hline & 1994 & 1995 & 1994 & 1995 & 1994 & 1995 \\
\hline 100 (control) & 20.1 & 23.1 & 28.4 & 49.2 & 26.5 & 24.2 \\
\hline 85 sustained & 18.0 & 35.2 & 32.8 & 66.6 & 35.0 & 24.5 \\
\hline 85 regulated & 6.1 & 13.5 & 8.2 & 22.1 & 24.2 & 14.5 \\
\hline 70 sustained & 7.1 & 15.5 & 8.4 & 17.2 & 21.5 & 14.2 \\
\hline 70 regulated & 4.7 & 5.4 & 2.2 & 2.2 & 35.8 & 18.8 \\
\hline Significance of $F, P=\mathrm{z}$ & 0.032 & 0.001 & 0.001 & 0.002 & 0.010 & 0.036 \\
\hline Orthogonal contrasts & & & & & & \\
\hline 100 versus deficits & 0.005 & 0.022 & 0.006 & 0.068 & NS & 0.063 \\
\hline 100 versus 85 sustained & NS & NS & NS & NS & 0.072 & NS \\
\hline 85 versus 70 & 0.030 & 0.007 & 0.003 & 0.003 & NS & NS \\
\hline Sustained versus regulated & 0.027 & 0.002 & 0.003 & 0.009 & NS & NS \\
\hline
\end{tabular}

$\overline{\mathrm{x}}$ Irrigation deficits of 70 and $85 \%$ of potential evapotranspiration (ETc) were imposed at every irrigation (70 and 85 sustained) or by one preharvest reduction to $50 \%$ of ETc from 1 June to 31 July ( 70 regulated) or 1 to 15 July ( 85 regulated).

y Average of 12 trees per replication. Dead wood consisted of spurs, twigs, and small branches and was visually estimated. Data collected 11 and 18 August 1994 and 1995, respectively, 2 days after trees were shaken for harvest.

${ }^{\mathrm{z}}$ Irrigation treatments were replicated six times and arranged in a randomized complete block design. NS $=$ not significant, $P>0.1000$. Means were separated by orthogonal contrasts. 



Fig. 1. Effects of deficit irrigation on the rate of maturation of almond fruit cultivar Nonpareil, Kern County, CA. Control trees were irrigated with $100 \%$ of the potential evapotranspiration requirement (ETc). Reductions to 85 or $70 \%$ of ETc were imposed at every irrigation (85S and $70 \mathrm{~S})$ or to $50 \%$ of ETc during one 2-week (85R) or 6-week (70R) period before harvest. On one tree in each of six replications of the irrigation treatments, 50 fruit that had not begun to abscise or dehisce were selected in July and rated weekly for 4 weeks in 1994 and 1995. The percentage of separation between the pedicel and hull was rated as $1=$ none, $2=$ less than $10 \%, 3=11$ to $25 \%, 4=26$ to $50 \%, 5=51$ to $75 \%, 6=76$ to $100 \%$, A. Dehisced fruit were defined as those with suture openings 2 or more $\mathrm{mm}$ wide, $\mathbf{B}$. Data are combined over years.
$85 \%$ of ETc or control treatments in 1994, and lower in the 85 sustained and $70 \%$ of ETc treatments than in the control in 1995 (Table 1). The average daily maximum temperatures were 36.7 and $34.2^{\circ} \mathrm{C}$ in July 1994 and 1995 , respectively. Daily high temperature exceeded twigs, not fruit infection, which does not damage the kernel. In these experiments, deficit irrigation during early fruit dehiscence had small or no effects on incidence of hull infection, but it dramatically reduced the amount of dead leaf clusters and dead fruiting wood. Decreasing amounts of water were generally accompanied by decreasing levels of disease, and both the manner in which the deficit was applied and the magnitude of water reduction were important. For instance, similar amounts of water applied either by maintaining irrigation at $85 \%$ of ETc throughout the season or by reduction from 100 to $50 \%$ of ETc during a single 2-week period produced two responses. In the first instance, hull rot incidence was not diminished. By contrast, the abrupt cutback to $50 \%$ of ETc reduced leaf and wood death by nearly two-thirds. Comparable relative differences in disease were found between the sustained and regulated deficit treatments that were supplied with $70 \%$ of ETc.

Tree water stress, as suggested by the predawn leaf water potential (PLWP) measurements, generally reflected the influence of the different irrigation regimes. Although the data could not be analyzed statistically, the lower PLWP values observed in mid-July, especially in 1995, indicate that water stress was greater during this period. Symptoms of water stress, such as partial defoliation, were not observed in the trees in this experiment, but the deficit irrigation regimes clearly diminished the incidence of hull rot symptoms. Infection of fewer hulls or interference with the production or transport of the toxin could reduce the amount of leaf and wood death. In our experiments, however, the percentages of naturally or artificially infected hulls were not correspondingly lessened by reductions in available water, thus hull infection alone cannot account for differences in leaf and wood death. Delayed fruit maturity would allow more time between dehiscence and harvest for toxins to be produced and moved into leaves, spurs, and twigs. In this study, the different rates of abscission and dehiscence reflected the relative amounts of leaf and wood death found among the irrigation treatments. Also, the 11-day period of temperatures exceeding $37^{\circ} \mathrm{C}$ during fruit dehiscence in July 1994 apparently stimulated more rapid ripening, which led to earlier harvest and less hull rot than occurred in the cooler year 1995 .

M. fructicola caused more hull rot than $R$. stolonifer in inoculation tests both years, and the two pathogens responded similarly to the irrigation treatments. However, $M$. fructicola, but not $R$. stolonifer, caused far more hull rot in 1995 than in 1994, suggesting that the cooler summer in 1995 particularly favored $M$. fructicola. The optimum temperature for growth is somewhat lower for $M$. fructicola $\left(22\right.$ to $24^{\circ} \mathrm{C}$ ) than for $R$. stolonifer $\left(27^{\circ} \mathrm{C}\right)(7,8)$. $37.2^{\circ} \mathrm{C}$ on $1,2,7$ to 18 , and 29 July 1994 and on 27, 28, and 31 July 1995.

\section{DISCUSSION}

The economic importance of hull rot lies in the destruction of fruiting spurs and 
Table 4. Effects of various deficit irrigation schedules on abscission, dehiscence, hull moisture content, and kernel weight of almond fruit cultivar Nonpareil, Kern County, CA

\begin{tabular}{|c|c|c|c|c|}
\hline Treatment & $\begin{array}{l}\text { Abscissionw } \\
\text { (rating) }\end{array}$ & $\begin{array}{c}\text { Dehisced } \\
\text { fruit }^{w}(\%)\end{array}$ & $\begin{array}{l}\text { Hull mois- } \\
\left.\text { turew }^{w} \%\right)\end{array}$ & $\begin{array}{c}\text { Kernel } \\
\text { weight }^{\mathbf{w}}(\mathrm{g})\end{array}$ \\
\hline \multicolumn{5}{|l|}{ Irrigation $^{\mathrm{x}}$} \\
\hline 100 (control) & $3.0^{\mathrm{y}}$ & 69.7 & 77.2 & 1.31 \\
\hline 85 sustained & 2.8 & 70.8 & 74.9 & 1.30 \\
\hline 85 regulated & 3.4 & 81.0 & 71.6 & 1.26 \\
\hline 70 sustained & 3.6 & 89.0 & 72.5 & 1.24 \\
\hline 70 regulated & 4.3 & 97.7 & 71.7 & 1.18 \\
\hline \multicolumn{5}{|l|}{ Year } \\
\hline 1994 & 4.2 & 90.3 & 73.6 & 1.19 \\
\hline 1995 & 2.7 & 72.9 & 73.6 & 1.32 \\
\hline \multicolumn{5}{|l|}{ Significance of $F, P=\mathrm{z}$} \\
\hline Irrigation & 0.0004 & 0.0001 & 0.0204 & 0.0002 \\
\hline \multicolumn{5}{|l|}{ Orthogonal contrasts } \\
\hline 100 versus deficits & NS & 0.0030 & 0.0040 & 0.0010 \\
\hline 100 versus 85 sustained & NS & NS & NS & NS \\
\hline 85 versus 70 & 0.0001 & 0.0001 & NS & 0.0010 \\
\hline Sustained versus regulated & 0.0050 & 0.0210 & NS & 0.0070 \\
\hline Year & 0.0001 & 0.0001 & NS & 0.0001 \\
\hline Irrigation $\times$ year & NS & NS & NS & NS \\
\hline
\end{tabular}

${ }^{\mathrm{w}}$ The abscission and dehiscence of 50 fruit on one tree in each replication of each irrigation treatment were rated on 29 July 1994 and 28 July 1995 on a scale of $1=$ none, $2=$ less than $10 \%, 3=11$ to $25 \%, 4=26$ to $50 \%, 5=51$ to $75 \%, 6=76$ to $100 \%$. Dehisced fruit were defined as those with suture openings that were $2 \mathrm{~mm}$ or more wide. Dry weight was determined from 75 kernels collected at harvest on 9 August 1994 and 16 August 1995.

${ }^{x}$ Irrigation deficits of 70 and $85 \%$ of potential evapotranspiration (ETc) were imposed at every irrigation (70 and 85 sustained) or by one preharvest reduction to $50 \%$ of ETc from 1 to 15 July (85 regulated) or 1 June to 31 July (70 regulated).

y Means are for main effects.

${ }^{\mathrm{z}}$ Irrigation treatments were replicated six times and arranged in a randomized complete block design. Overall significances of $F$ are for main effects and their interactions. Means were separated by orthogonal contrasts. NS $=$ not significant, $P>0.1000$.

Much of the epidemiology of hull rot remains unknown. Soil and organic debris in the orchard are thought to be sources of $R$. stolonifer, and M. fructicola is probably introduced from nearby stone fruit orchards. Both perhaps survive on infected fruit. Spores of both fungi are readily airborne, but nitidulid beetles have been implicated as well (7). Preparation of the orchard floor for harvest occurs during fruit dehiscence and causes clouds of dust that could easily disseminate soil-borne spores to the opening fruit. The roles of temperature and relative humidity in the development of hull rot disease have not been investigated.

Imposing water stress on trees at early fruit dehiscence does not come without a price. Kernel weight was reduced in all deficit treatments except the $85 \%$ sustained deficit irrigation. A full discussion of the effects of these irrigation treatments on yield is beyond the scope of this report, but fruit load, the other primary almond yield component, was unaffected by the deficit irrigation regimes (D. A. Goldhamer, unpublished data). Other studies have demonstrated that preharvest deficit irrigation can improve almond fruiting density (3).
Thus, any yield-related profit reduction from the deficit irrigation regimes evaluated in this study is probably associated with reduced kernel size, which we believe to be minimal relative to the benefits associated with reduced hull rot.

The principle of reduced irrigation before harvest to control hull rot is well established $(7,11)$. The difficulty lies in applying this practice to individual orchards, which vary in irrigation method and frequency, soil water-holding capacity, and tree age, among other things. These elements, along with weather, influence the amount and duration of deficit irrigation that is needed without causing unnecessary harm to the tree or its crop. We recognize that growers need a reliable method to monitor the water status of their trees during deficit irrigations. While we used PLWP measurements to quantify tree water stress, other techniques, such as using midday stem water potential, may be more attractive to growers (9). More work is needed to develop target tree water status values and improved monitoring techniques to minimize hull rot without sacrificing kernel size. At present, many growers will likely rely upon their experience and judgment to achieve slight water stress without risking yield loss when reducing irrigation during early fruit dehiscence. The development of better guidelines for implementation of this practice is the subject of another study.

\section{LITERATURE CITED}

1. Browne, L. T., Ogawa, J. M., and Gashaira, B 1977. Search continues for control of almond hull rot. Calif. Agric. 31(1):16-17.

2. Fereres, E., and Goldhamer, D. A. 1990 Deciduous fruit and nut trees. Pages 987-1017 in: Irrigation of Agricultural Crops. B. A Stewart and D. R. Nielsen, ed. Am. Soc Agron., Madison, Wis. (Monogr. 30).

3. Goldhamer, D. A., and Viveros, M. 2000 Effects of preharvest irrigation cutoff durations and postharvest water deprivation on almond tree performance. Irr. Sci. Vol. 19(3):125-131.

4. Hsiao, T. C. 1990. Measurements of plant water status. Pages 243-279 in: Irrigation of Agricultural Crops. B. A. Stewart and D. R. Nielsen, eds. Am. Soc. Agron., Madison, Wis. (Monogr. 30)

5. Mirocha, C. J., DeVay, J. E., and Wilson, E. E. 1961. Role of fumaric acid in the hull rot disease of almond. Phytopathology 51:851-860.

6. Mirocha, C. J., and Wilson, E. E. 1961. Hull rot disease of almond. Phytopathology 51:843-847.

7. Ogawa, J. M., and English, H. 1991. Diseases of temperate zone tree fruit and nut crops Univ. Calif. Div. Agric. Nat. Resourc. Publ. 3345.

8. Pierson, C. F. 1966. Effect of temperature on growth of Rhizopus stolonifer on peaches and agar. Phytopathology 56:276-278.

9. Shackel, K., Ahmadi, H., Biasi, W., Buchner, R., Goldhamer, D., Gurusinghe, S., Hasey, J. Kester, D., Krueger, B., Lampinen, B., McGourty, G., Micke, W., Mitcham, E., Olson, B., Pelletrau, K., Philips, H., Ramos, D., Schwankl, L., Sibbett, S., Snyder, R., Southwick, S., Stevenson, M., Thorpe, M., Weinbaum, S., and Yeager, J. 1997. Plant water status as an index of irrigation need in deciduous fruit trees. HortTechnology 7(1):2329

10. Snyder, R. L., and Pruitt, W. O. 1989. Reference evapotranspiration. Pages 24-27 in: Irrigation Scheduling: A Guide for Efficient OnFarm Water Management. D. A. Goldhamer and R. L. Snyder, eds. Univ. Calif. Div. Agric. Nat. Resourc. Publ. 21454

11. Teviotdale, B. L., Michailides, T. J., Goldhamer, D. A., and Viveros, M. 1994. Reduction of almond hull rot disease caused by Rhizopus stolonifer by early termination of preharvest irrigation. Plant Dis. 79:402-405

12. Teviotdale, B. L., Michailides, T. J., Goldhamer, D. A., and Viveros, M. 1995. Effects of hull abscission and inoculum concentration on severity of leaf death associated with hull rot of almond. Plant Dis. 80:809-812.

13. University of California. 1985. Insects and mites. Pages 49-91 in: Integrated Pest Management for Almonds. Univ. Calif. Div. Agric. Nat. Resourc. Publ. 3308

14. University of California. 1985. Branch, Foliage, and Fruit Diseases. Pages 108-118 in: Integrated Pest Management for Almonds. Univ. Calif. Div. Agric. Nat. Resourc. Publ. 3308. 